\title{
Potential for Genetic Damage from Multivitamin Solutions Exposed to Phototherapy Illumination
}

\author{
JOHN F. ENNEVER, ${ }^{(20)}$ HOWARD S. CARR, AND WILLIAM T. SPECK ${ }^{(18)}$ \\ Department of Pediatrics, Rainbow Babies and Childrens Hospital, Case Western Reserve University School of \\ Medicine, Cleveland, Ohio, USA
}

\begin{abstract}
Summary
The ability of standard phototherapy illumination to produce damage in intracellular DNA is well established. In this study, the addition of a dilute solution (1:6400) of a clinically-used multivitamin concentrate to human $\mathrm{KB}$ cells was found to enhance the generation of single-strand DNA breaks produced by broad-spectrum fluorescent light. The effect of the exogenous photosensitizing agent (multivitamins) was blocked by the enzyme catalase; thus, the photoproduct responsible for the DNA modification was hydrogen peroxide, an extremely reactive molecule capable of damaging a variety of biologic macromolecules.
\end{abstract}

Abbreviations

PBS, phosphate buffered saline

D5PBS, 5\% (w/v) dextrose in phosphate buffered saline

The efficacy of phototherapy in the treatment of neonatal hyperbilirubinemia is well established and its usage widespread (2). Recently, concern has been expressed about the potential long-term side effects of this treatment regimen, and more specifically, its carcinogenic and/or teratogenic potential (12). Such concerns seem justified in view of DNA modifying activity of phototherapy (9), a property shared with many chemical carcinogens and teratogens (1). The photodynamic damage of intracellular DNA has been well characterized and is enhanced by, but not dependent upon, the presence of exogenous photosensitizing agents $(3,7,10,11)$. Such enhancement takes on clinical significance when it is realized that many low birth-weight infants receiving phototherapy are simultaneously administered parenteral hyperalimentation solutions containing photosensitizers, i.e., multivitamins, amino acids, etc. The effect of illuminating solutions of multivitamins on the integrity of human intracellular DNA is examined in this report.

\section{MATERIALS AND METHODS}

All chemicals were reagent grade and were obtained from commercial supply houses. Bovine catalase (EC 1.11.1.6) and serum albumin were purchased from Sigma Chemical Co. (15). Multivitamin solution (M.V.I. Concentrate) was obtained from USV Pharmaceutical Corp. (16). According to the manufacturer each $\mathrm{ml}$ of M.V.I. Concentrate contains: $100 \mathrm{mg}$ ascorbic acid, 2000 I.U. vitamin A, 200 I.U. vitamin D, $10 \mathrm{mg}$ thiamine $\mathrm{HCl}, 2$ $\mathrm{mg}$ riboflavin, $3 \mathrm{mg}$ pyridoxine $\mathrm{HCl}, 20 \mathrm{mg}$ niacinamide, $5 \mathrm{mg}$ dexpanthenol, I I.U. vitamin E (di- $\alpha$-tocopheryl acetate).

Human KB cells were grown in stationary culture in Eagle's Minimal Essential Medium containing glutamine (17) supplemented with $10 \%$ calf serum. $\left[{ }^{3} \mathrm{H}\right]$-Thymidine $(77 \mathrm{mCi} / \mathrm{mmole})$ was added to each $25 \mathrm{~cm}^{2}$ flask to yield a final radiosotope concentration of $2 \mu \mathrm{Ci} / \mathrm{ml}$. After a $24-30 \mathrm{~h}$ incorporation period, the $\left[{ }^{3} \mathrm{H}\right]$-thymidine was removed, the cell monolayer was rinsed with phosphate buffered saline (PBS), fresh media added and the cells were reincubated for an additional 10-24 h. The cells were subsequently washed with PBS and each flask supplemented with $5 \mathrm{ml}$ portions of $5 \%(\mathrm{w} / \mathrm{v})$ of dextrose in PBS (D5PBS). In some experiments, as described in "Results", additional additives were included in the D5PBS. All flasks were incubated for $30 \mathrm{~min}$ at $37^{\circ} \mathrm{C}$ in the dark, whereupon some flasks were illuminated under a standard phototherapy unit equipped with eight broad-spectrum fluorescent lights (Duro-Test Vita Lite) at a fluence of $150 \mu \mathrm{W} /$ $\mathrm{cm}^{2}$ (measured with an IL600A photometer coupled to an IL600A photodensitometer manufactured by International Light, Inc.). The flasks were forced air cooled to maintain a temperature of $23^{\circ} \mathrm{C}$.

After illumination (or a corresponding control period in the dark at $23^{\circ} \mathrm{C}$ ), the cells were washed with PBS and removed from the flask by trypsinization. Approximately 3000 cells were lysed for $1 \mathrm{~h}$ in $0.3 \mathrm{ml}$ of $0.2 \%$ (w/v) sarcosyl, $0.5 \mathrm{M} \mathrm{NaOH}, 0.1 \mathrm{M}$ EDTA (free acid) on the top of a $5 \mathrm{ml}$ gradient of $5-20 \%(\mathrm{w} / \mathrm{v}$ ) sucrose containing $0.3 \mathrm{M} \mathrm{NaOH}, 0.7 \mathrm{M} \mathrm{NaCl}$ and $1 \mathrm{mM}$ EDTA. After lysis, the gradients were centrifuged in a Beckman SW50.1 rotor for $1 \mathrm{~h}$ at $38,000 \mathrm{rpm}(135,000 \times \mathrm{g})$ at $20-23^{\circ} \mathrm{C}$. Fractions ( 5 drop) were collected from the top of the gradient and precipitated with $5 \%$ trichloroacetic acid. The precipitate was collected by vacuum filtration on glass fiber filters (Whatman type GF/C). After drying, the filters were placed in $7 \mathrm{ml}$ of a toluene-based scintillant (Omnifluor) and the radioactivity was determined in a Beckman LS7500 liquid scintillation counter.

\section{RESULTS}

Illumination of $\mathrm{KB}$ cells for $30 \mathrm{~min}$ in the absence of photosensitizers (multivitamins) had no effect on the sedimentation pattern of intracellular DNA, more specifically, only high molecular weight DNA was found (Fig. 1). This sedimentation pattern was indistinguishable from that observed for control cells kept in the dark (data not shown). But when a multivitamin solution was added to the cells at a dilution of 1:6400 and subsequently exposed to $30 \mathrm{~min}$ of illumination, extensive breakdown of the cellular DNA occurred. This breakdown is detected as slower sedimenting radioactive material in the sucrose gradient (Fig. 1). Cells, which had been incubated in the dark for a comparable period of time and in the same concentration of multivitamins, demonstrated no detectable DNA damage (Fig. 1). When cells were incubated with higher concentrations of multivitamins, DNA damage was detectable at proportionally lower levels of illumination. Evidence for intracellular DNA damage was also found when a 1:6400 dilution of multivitamins was illuminated for $30 \mathrm{~min}$, followed by a 60 min incubation (at $23^{\circ} \mathrm{C}$ ) in the dark of this preilluminated solution with KB cells (data not shown); thus, a stable photoproduct is responsible for the observed DNA modification.

When $\mathrm{KB}$ cells were illuminated in the presence of multivitamins as described above and the enzyme catalase $(1 \mathrm{mg} / \mathrm{ml})$, the DNA sedimentation pattern shown in Figure 2 was observed. This gradient, in which only high molecular weight DNA was found, demonstrates that catalase protects the intracellular DNA from the photodynamic damage produced by the multivitamin solution; moreover, if the catalase was first denatured by boiling for $10 \mathrm{~min}$ 


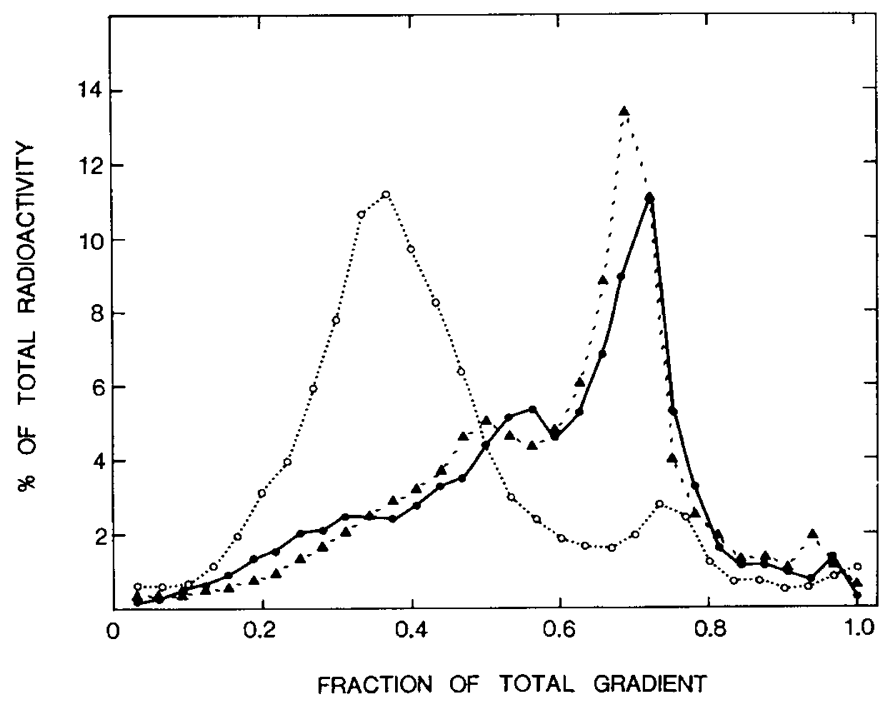

Fig. 1. Alkaline sucrose gradient sedimentation patterns for DNA isolated from human cells exposed to phototherapy illumination with and without multivitamins. Sedimentation is from left to right. (- $) \mathrm{KB}$ cells in D5PBS illuminated as described in "Materials and Methods." $\left(\mathrm{O}-\mathrm{O}_{-\mathrm{O}} \mathrm{KB}\right.$ cells illuminated in D5PBS and 1:6400 dilution of multivitamins. ( $\triangle---\mathbf{A}) \mathrm{KB}$ cells in D5PBS and 1:6400 dilution of multivitamins incubated in the dark.

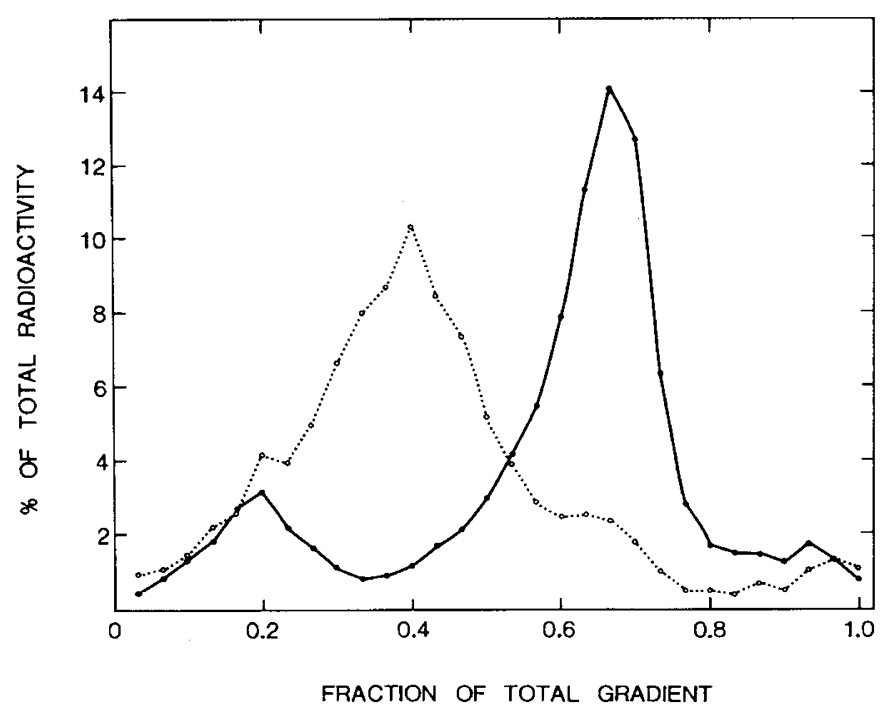

Fig. 2. Effect of catalase on the DNA-modifying activity of multivitamin solutions exposed to visible light. (-) DNA from KB cells exposed to $30 \mathrm{~min}$ of illumination in D5PBS and 1:6400 dilution of multivitamins with $1 \mathrm{mg} / \mathrm{ml}$ catalase. $\left(\mathrm{O}_{---} \mathrm{O}\right)$ Identical to previous sample except catalase boiled for $10 \mathrm{~min}$ before illumination. Sedimentation is from left to right.

before inclusion to the illumination assay, the protective effect of catalase was eliminated (Fig. 2). This demonstrates that the protective effect of catalase is due to its enzymatic activity, i.e., the reduction of hydrogen peroxide to water and molecular oxygen.

\section{DISCUSSION}

Previous investigators have shown that illumination with fluorescent light is lethal for human cells in synthetic tissue culture medium (6). Similar illumination of cells supplemented with physiologic photosensitizers before exposure to visible light has recently been shown to produce single-strand breaks in intracellular DNA (5). The photoproduct responsible for these effects is hydrogen peroxide. Furthermore, it was determined that this reactive molecule was generated after illuminated of riboflavin in the presence of either tryptophan or tyrosine, both normal constituents of tissue culture medium $(5,14)$. The present study demonstrates that illumination of human cells in the presence of dilute concentrations of multivitamins results in photochemical changes in intracellular DNA. Furthermore, the photoproduct responsible for the DNA damage is a peroxide, most likely hydrogen peroxide although other organic peroxides which also can be reduced by catalase have not been excluded. The mechanism(s) responsible for photoproduction of the peroxide in this system has not been determined; however, the absence of tryptophan or tyrosine in multivitamin preparations suggests that the observed changes are not analogous to those previously described following illumination of human cells in tissue culture medium $(5,14)$.

Our observations do not exclude a roll for riboflavin in the photodynamic alterations of intracellular DNA. High concentrations of light-activated riboflavin $(25 \mu \mathrm{g} / \mathrm{ml})$ modify intracellular DNA; however, such effects are dose-dependent and not observed at concentrations of riboflavin of $10 \mu \mathrm{g} / \mathrm{ml}$ or less (the final concentration of riboflavin present in the multivitamin dilution used in this study was $0.3 \mu \mathrm{g} / \mathrm{ml})(4,11)$. DNA-modifying activity of light-activated riboflavin is not dependent upon the generation of hydrogen peroxide; thus, if riboflavin is responsible for the photodynamic modifications of DNA described in this report, it is acting synergistically with one or more of other components in the multivitamin solutions.

These results, which demonstrate the ability for light-treated multivitamin solutions to modify human intracellular DNA, are disconcerting when it is realized that many carcinogens and/or teratogens derive their activity from a similar ability to modify DNA. The potential for long-term sequellae for infants simultaneously receiving parenteral nutrition and phototherapy is significant (13). Hydrogen peroxide is an extremely reactive molecule capable of damaging various macromolecules and may be responsible for some of the short-term side effects, i.e., the hepatocellular dysfunction observed in infants receiving parenteral hyperalimentation (8). Pending the results of additional biochemical studies to more fully characterize the photochemical reactions described in this report, we would recommend protecting multivitamin solutions from exposure to visible light.

\section{REFERENCES AND NOTES}

1. Ames, B. N., Lee, F. D., and Durston. W. E.: An improved bacterial test system for the detection and classification of mutagens and carcinogens. Proc. Natl. Acad. Sci. USA, 70: 2271 (1973).

2. Behrman, R. E. Brown, A. K. Currie, M. R., Hastings, J. W., Odell, G. B. Schaffer, R., Setlow, R. B., Vogl, T. P., Wurtman, F. J., Anderson, R. J., Kostkowski, H. J., and Simpouolos, A. P.: Preliminary report of the committee on phototherapy in the newborn infant. J. Pediatr., 84: 135 (1974).

3. Bradley, M. O. and Sharkey, N. A.: Mutagenicity and toxicity of visible fluorescent light to cultured mammalian cells. Nature (Lond), 266: 724 (1977).

4. Ennever, J. F.: unpublished observations.

5. Hoffman, M. E. and Meneghini, R.: DNA strand breaks in mammalian cells exposed to light in the presence of riboflavin and tryptophan. Photochem. Photobiol., 29: 299 (1979).

6. Nixon, B. T. and Wang, R.: Formation of photoproducts lethal for human cells in culture by "daylight" fluorescent light and bilirubin light. Photochem. Photobiol., 26: 589 (1977)

7. Pereira, O. M., Smith, J. R., and Packer, L.: Photosensitization of human diploid cell cultures by intracellular flavins and protection by antioxidants. Photochem. Photobiol., 24: 237 (1976)

8, Postum, R. and Trevenen, C. L.: Liver disease in infants receiving total parenteral nutrition. Pediatrics, 63: 110 (1979).

9. Santella, R. M., Rosenkranz, H. S., and Speck, W. T.: Intracellular deoxyribonucleic acid-modifying activity of intermittent phototherapy. J. Pediatr., 93: 106 (1978).

10. Sideris, E. G., Papageorgiou, G. C., Charalampous, S. C., and Vistsa, E. M.: A spectrum response study on single strand DNA breaks, sister chromatid exchanges, and lethality induced by phototherapy lights. Pediatr. Res., 15: 1019 (1981).

11. Speck, W. T., Chen, C. C., and Rosenkranz, H. S.: In vitro studies of light and riboflavin on DNA and HeLa cells. Pediatr. Res., 9: 150 (1975).

12. Speck, W. T. and Rosenkranz, H. S.: Phototherapy for neonatal hyperbilirubinemia-a potential environmental health hazard to newborn infants. Environ. Mutagen., I: 32I (1979).

13. Vileisis, R. A., Sorensen, K., Gonzales-Crussi, F., and Hunt, C. E.: Liver malignancy after parenteral nutrition. J. Pediatr., 100: 88 (1982). 
14. Wang, R. J. and Nixon, B. T.: Identification of hydrogen peroxide as a photoproduct toxic to human cells in tissue-culture medium irradiated with "daylight" fluorescent light. In Vitro, 14: 715 (1978).

15. St. Louis, MO.

16. Tuckahoe, NY.

17. Flow laboratories, McLean, VA.

18. Recipient of a National Institutes of Health Research Career Development

Copyright (C) 1983 International Pediatric Research Foundation. Inc. 003I-3998/83/1703-0192\$02.00/0
Award $1 \mathrm{KO}-4-\mathrm{CA}-00443$.

19. Supported by Grant CA-23692-04 from the National Cancer Institute.

20. Requests for reprints should be addressed to: John F. Ennever, Ph.D., M.D.,

Department of Pediatrics, Rainbow Babies and Childrens Hospital, 2101 Adelbert Road, Cleveland, $\mathrm{OH} 44106$.

21. Received for publication February 24, 1982.

22. Accepted for publication June 21, 1982. 